\title{
ANALISIS FONETIK BAHASA KOMERING DI DESA KURUNGAN NYAWA DAN DESA RIANG BANDUNG ULU
}

\author{
Indah Sulmayanti ${ }^{1 *}$, Eni Anggraini ${ }^{2}$ \\ Program Studi Pendidikan Bahasa dan Sastra Indonesia \\ STKIP Nurul Huda OKU Timur \\ Indah81@stkipnurulhuda.ac.id \\ Aeni7964@gmail.com
}

\begin{abstract}
Abstrak
Bahasa Komering merupakan salah satu Bahasa daerah yang digunakan di OKU Timur Sumatera Selatan. Bahasa Komering terdapat perbedaan dalam pengucapan dari segi fonetik dan memunculkan makna yang berbeda-beda sehingga menarik untuk diteliti. Rumusan penelitian ini adalah bagaimanakah Perbedaan fonetik Bahasa Komering Desa Kurungan Nyawa dan Desa Riang Bandung Ulu. Tujuan artikel ini mendeskripsikan perbedaan fonetik bahasa Komering Desa Kurungan Nyawa dan Desa Riang Bandung Ulu. Metode yang digunakan adalah metode kualitatif dengan pendekatan studi deskriptif analitik. Hasil penelitian ini adalah deskripsi dari perbedaan fonetik bahasa Komering Desa Kurungan Nyawa dan Desa Riang Bandung Ulu, simpulan dari analisis fonetik bahasa Komering terdapat 4 perbedaan. Pertama, pada Desa Kurungan Nyawa mengunakan monoftong e, sedangkan Desa Riang Bandung Ulu mengunakan monoftong o. Kedua, artikulator Kurungan Nyawa yang digunakan adalah gerak lidah bagian depan dan dengan posisi bibir yang tidak bulat sedangkan Riang Bandung Ulu adalah adalah gerak lidah bagian belakang dan dengan posisi bibir yang bulat. Ketiga, Kurungan Nyawa banyak mengunakan konsonan hambat letup sedangkan Riang Bandung Ulu pengunaan konsonan tidak mendominasi. Keempat, Kurungan Nyawa mengunakan konsonan $\underline{h}$ atau geseran laringal dan konsonan $\underline{s}$ atau geseran lamino alveolar sedangkan Riang Bandung Ulu mengunakan konsonan $\underline{r}$ atau getar apiko alveolar.
\end{abstract}

Kata Kunci: Analisis, fonetik, Bahasa Komering

\section{PENDAHULUAN}

Bahasa merupakan unsur yang tidak dapat dipisahkan dengan manusia dalam kehidupan kesehariannya. Manusia dalam kehidupan sehari-hari tidak terlepas menggunakan bahasa sebagai alat ucap. Bahasa adalah bagian dari kehidupan manusia untuk berkomunikasi sesama manusia. Bahasa sebagai alat komunikasi, bahasa merupakan saluran perumusan maksud kita, melahirkan perasaan dan kemungkinan menciptakan kerjasama dengan sesama warga (Keraf, 2004:4).

Di Sumatera Selatan terdapat lima kelompok bahasa, yaitu kelompok bahasa Komering, Melayu, Bugis, Jawa, dan Bali. Lima kelompok bahasa itu, terdapat dua kelompok bahasa yang merupakan kelompok bahasa asli daerah Sumatera Selatan, yaitu Komering dan Melayu, sedangkan tiga kelompok bahasa lainnya, yaitu Bugis, Jawa, dan Bali merupakan kelompok bahasa yang berasal dari etnis pendatang yang mendiami beberapa wilayah di Sumatera Selatan (Irsan, 2008:33).

Satu kelompok bahasa asli Sumatera Selatan yaitu bahasa Komering sebagai salah satu bahasa berperan juga dalam pengembangan kosakata bahasa Indonesia. Bahasa Komering mempunyai ciri tersendiri yang berbeda dari bahasa-bahasa dan dialek-dialek lainnya di Sumatera Selatan. Perbedaan itu tidak hanya dalam bentuk kosakata, tetapi juga dalam struktur dan intonasinya. Hingga saat ini, bahasa Komering masih digunakan secara aktif oleh penuturnya, yakni suku Komering dalam komunikasi sehari-hari. Selain menguasai bahasa Komering sebagai bahasa ibu, suku Komering juga dapat berbahasa Melayu Palembang sebagai bahasa pengantar (lingua franca) dalam komunikasi antar suku di Sumatera Selatan. Selain itu, mereka juga mampu berbahasa Indonesia sebagai bahasa resmi atau bahasa pengantar di tingkat nasional.

Wilayah Sumatera Selatan yang mengunakan bahasa Komering sebagai alat komunikasi salah satunya adalah Ogan Komering Ulu Timur (OKU Timur). Bahasa Komering memiliki ciri-ciri yang berbeda dari ciri bahasa daerah yang termasuk kedalam kelompok bahasa Melayu lainnya. Masyarakat 
OKU Timur mengetahui banyak ragam bahasa yang ada di Indonesia ini, begitu pula dengan bahasa Komering, bukan hanya satu bahasa yang ada. Walaupun suku Komering hanya satu tetapi bahasanya banyak memiliki perbedaan cara pengucapannya dan arti yang berbeda-beda. Perbedaan pengunaan bahasa Komering antara daerah satu dengan daerah lainnya pada saat terjadinya komunikasi antara orang Komering yang tinggal agak berjauhan akan sangat berbeda pada cara pengucapan maupun artinya akan berbeda-beda. Hal inilah yang menjadi menarik dan unik ketika menyimak percakapan antara orang Komering yang berbeda domisili. Pengucapan kosakata bahasa Komering setiap daerah juga memiliki dialek sangat khas. Hal ini menarik perhatian peneliti sebagai orang yang bersuku Komering. Peneliti tertarik apakah yang menjadi pembedaan cara pengunaan bahasa Komering antara daerah satu dengan daerah lainnya dilihat dari segi fonetik. Fonetik merupakan bidang yang berkaitan erat dengan kajian bagaimana cara manusia berbahasa serta mendengar dan memproses ujaran yang diterima. Lebih lanjut fonetik ini sangat berguna untuk tujuan-tujuan seperti pengajaran diksi, dan menjelaskan ujaran bunyi-bunyi bahasa Komering yang berbeda antara satu daerah dengan daerah yang lainnya.

Perbedaan pengunaan bahasa Komering tersebut juga terjadi di dua desa di Kabupaten OKU Timur yaitu Desa Kurungan Nyawa Kecamatan Buay Madang dan Riang Bandung Ulu Kecamatan Madang Suku II. Kedua desa tersebut merupakan tempat tumbuh kembang suku Komering di daerah OKU Timur. Kedua tempat tersebut juga merupakan daerah yang berada di tepian sungai Komering yang pengunaan dialek bahasa Komering secara signifikan berbeda. Perbedaan pengunaan dialek antara masyarakat Desa Kurungan Nyawa dan Riang Bandung Ulu tersebut inilah yang melatarbelakangi penelitian ini. Peneliti tertarik untuk mengkaji perbedaan-perbedaan tersebut meskipun sesama suku Komering yang mengunakan bahasa Komering.

Latar penelitian dari penelitian ini adalah dari keunikan ketika komunikasi terjadi antara dua orang suku Komering yang bertempat tinggal berjauhan. Peneliti tertarik apakah yang menjadi pembedaan cara pengunaan bahasa Komering antara daerah satu dengan daerah lainnya dilihat dari segi fonetik. Perbedaan pengunaan bahasa Komering tersebut juga terjadi di dua desa di Kabupaten OKU Timur yaitu Desa Kurungan Nyawa Kecamatan Buay Madang dan Riang Bandung Ulu Kecamatan Madang Suku II. Kedua desa tersebut merupakan tempat tumbuh kembang suku Komering di daerah OKU Timur. Perbedaan yang secara signifikan sangat terdengar jelas pada saat berkomunikasi antara 2 orang Komering yang berbeda wilayah tempat tinggal adalah bunyi bahasa. Sehingga penelitian ini akan mengkaji bahasa Komering dari segi ilmu fonetik.

\section{METODE PENELITIAN}

Jenis penelitian yang digunakan dalam penelitian ini adalah penelitian kualitatif karena digunakan untuk memperoleh data untuk memberikan gambaran objek berdasarkan masalah yang diangkat yaitu perbedaan fonetik bahasa Komering di Desa Kurungan Nyawa dan Riang Bandung Ulu. Metode yang digunakan dalam penelitian ini adalah metode deskriptif karena penulis ingin mengungkapkan, menggambarkan, dan memaparkan perbedaan fonetik bahasa Komering di Desa Kurungan Nyawa dan Riang Bandung Ulu. Pendekatan dalam penelitian ini adalah pendekatan sosiolinguistik. Sosiolinguistik merupakan kajian tentang bahasa yang dikaitkan dengan kondisi kemasyarakatan. Sumber data dalam penelitian ini adalah bahasa Komering yang ada di Kurungan Nyawa dan Riang Bandung Ulu. Teknik pengumpulan data mengunakan menggunakan studi dokumentasi. Terakhir, teknik analisis data yaitu dengan mengikuti prosedur teori analisis padan intralingual.

\section{HASIL DAN PEMBAHASAN}

\section{Hasil}

Data dalam penelitian ini mengunakan 3 narasumber dari 2 desa yang diteliti yaitu Desa Kurungan Nyawa dan Riang Bandung. Untuk mempermudah proses penelitian maka data yang diperoleh dari 3 narasumber tersebut dikelompokkan menjadi 3 tema pokok bahasan. Pengelompokan tersebut didasari daripada masing-masing bahasa percakapan sehari-hari tiap narasumber. Narasumber 1 berjumlah 2 orang berasal dari 2 desa berbeda dalam percakapannya mengangkat bahasan tentang pendidikan, narasumber 2 berjumlah 2 orang berasal dari 2 desa berbeda dalam percakapannya mengangkat 
ANALISIS FONETIK BAHASA KOMERING DI DESA .... $\left.\right|_{3}$ bahasan tentang makanan, dan narasumber 3 berjumlah 2 orang berasal dari 2 desa berbeda dalam percakapanya mengangkat bahasan tentang budaya orang Komering.

Penelitian pertama terhadap fonetik artikulatoris pada kosakata bahasa Komering dalam percakapan sehari-hari tentang makanan dan minuman, penelitian kedua terhadap fonetik artikulatoris pada kosakata bahasa Komering dalam percakapan sehari-hari tentang kata sifat, serta penelitian ketiga fonetik artikulatoris pada kosakata bahasa Komering dalam percakapan sehari-hari tentang kata kerja. Masing-masing pokok bahasan diambil 20 kosakata yang diteliti. Diharapkan dari ketiga pokok pembahasan yang diteliti dapat memberikan gambaran secara menyeluruh tentang fonetik bahasa Komering di Desa Kurungan Nyawa dan Riang Bandung Ulu.

\section{Pembahasan}

Fonetik Artikulatoris Narasumber Pertama Tentang Makanan dan Minuman pada Percakapan Sehari-hari. Pembahasan mendeskripsikan hasil analisis terhadap perbedaan fonetik bahasa Komering di Desa Kurungan Nyawa dan Desa Riang Bandung Ulu yang ditemukan di lapangan disesuaikan dengan kajian fonetik artikulatoris. Ada 3 pembahasan yaitu kaitan dengan kosakata dalam percakapan sehari-hari tentang makanan dan minuman, kata kerja dan kata sifat. Kosa kata dalam percakapan sehari-hari masing-masing diambil dari 20 kosakata yang diteliti agar dalam proses pengambilan hasil penelitian dapat akurat dan benar dengan sesuai penemuan dilapangan. Berikut 3 deskripsi pembahasan hasil analisis perbedaan bahasa Komering di Desa Kurungan Nyawa dan Desa Riang Bandung Ulu.

Pada kata tempuyak dan tempoyak tersebut termasuk monoftong, meskipun berbeda posisi lidah ketika mengucapkannya. Jika vokal $\underline{u}$ pada kata tempuyak, lidah dalam posisi tinggi atas, gerak lidah bagian belakang striktur tertutup serta bentuk bibir yang bulat. Sedangkan vokal o pada kata tempoyak, lidah dalam posisi madya atas, gerak lidah bagian belakang, striktur semi tertutup serta bentuk bibir yang bulat.

Pada kata agar dan agor tersebut menunjuk-kan struktur yaitu vokal a dan o yang merupakan vokal terbuka atau open vowels. Vokal tersebut dibentuk dengan lidah dalam posisi serendah mungkin, kira-kira pada garis yang menghubungkan antara a dan $\underline{0}$.

Pada kata serebat dan surbat tersebut termasuk monoftong meskipun berbeda posisi lidah ketika mengucapkannya. Jika vokal e pada kata serebat, lidah dalam posisi madya atas, gerak lidah bagian depan, striktur semi tertutup, serta bentuk bibir yang tak bulat. Sedangkan vokal u pada kata surbat, lidah dalam posisi tinggi atas, gerak lidah bagian belakang striktur tertutup serta bentuk bibir yang bulat.

Pada kata Bawung dan Bawong tersebut termasuk monoftong, meskipun berbeda posisi lidah ketika mengucapkannya. Jika vokal $\underline{u}$ pada kata Bawung, lidah dalam posisi tinggi atas, gerak lidah bagian belakang striktur tertutup serta bentuk bibir yang bulat. Sedangkan vokal o pada kata Bawong, lidah dalam posisi madya atas, gerak lidah bagian belakang, striktur semi tertutup serta bentuk bibir yang bulat.

Pada kata bayom, konsonan $\underline{b}$ merupakan konsonan hambat letup bilabial lunak bersuara yang terjadi bila penghambat artikulator aktifnya adalah bibir bawah dan artikulator pasifnya adalah bibir atas. Sedangkan pada kata hayom, konsonan $\underline{h}$ merupakan konsonan geseran laringal atau geseran glottal terjadi bila artikulatornya adalah sepasang pita suara, udara yang dihembuskan dari paru-paru pada waktu melewati glottis digeserkan, dan posisi terbuka, posisi terbuka ini lebih sempit dari pada posisi glottis terbuka lebar saat bernafas normal. Maka terjadilah bunyi $\underline{h}$.

Pada kata tahlui dan hatolui, konsonan $\underline{h}$ dan $\underline{t}$ sama-sama ada tetapi dalam posisi letak yang berbeda. Jika konsonan $\mathrm{h}$ terjadi dikarenakan bila artikulatornya adalah sepasang pita suara, udara yang dihembuskan dari paru-paru pada waktu melewati glottis digeserkan, dan posisi terbuka, posisi terbuka ini lebih sempit dari pada posisi glottis terbuka lebar saat bernafas normal sehingga disebut konsonan geseran laringal atau geseran glottal. Sedangkan $\underline{t}$ terjadi bila penghambat artikulator aktifnya adalah ujung dan artikulator pasifnya ialah gigi atas sehingga bunyi t adalah konsonan keras tak bersuara atau disebut konsonan hambat letup apikodental.

Pada kata kemurak dan kamurak, vokal a dan e merupakan monoftong yang memiliki persamaan pada gerak lidah yaitu depan. Jika vokal e tinggi lidah berada pada posisi madya atas, striktur semi tertutup, dan bentuk bibir tak bulat. Sedangkan vokal a rendah lidah berada di bawah, striktur terbuka dan bentuk bibir tak bulat.

Pada kata belu dan bolu, merupakan monoftong yang berbanding terbalik. Jika vokal $\underline{\text { e }}$ tinggi lidah 
berada pada posisi madya atas, striktur semi tertutup, dan bentuk bibir tak bulat. Sedangkan vokal $\underline{0}$ lidah dalam posisi madya atas, gerak lidah bagian belakang, striktur semi tertutup serta bentuk bibir yang bulat.

Pada kata bumbu dan humbu merupakan kata reduplikasi. Jika konsonan $\underline{\mathrm{b}}$ merupakan konsonan hambat letup bilabial lunak bersuara yang terjadi bila penghambat artikulator aktifnya adalah bibir bawah dan artikulator pasifnya adalah bibir atas. Sedangkan konsonan $\underline{h}$ terjadi dikarenakan bila artikulatornya adalah sepasang pita suara, udara yang dihembuskan dari paru-paru pada waktu melewati glottis digeserkan, dan posisi terbuka, posisi terbuka ini lebih sempit dari pada posisi glottis terbuka lebar saat bernafas normal sehingga disebut konsonan geseran laringal atau geseran glottal.

Pada kata kukkuk dan kukuk memiliki konsonan $\underline{\mathrm{k}}$, yang membedakan pengunaan konsonan $\underline{\mathrm{k}}$ yang digandakan dan tunggal. Sehingga konsonan $\underline{k}$ yang dipakai ganda lebih tajam dibandingkan dengan yang tunggal. Konsonan $\mathrm{k}$ sendiri yaitu konsonan hambat letup dorso velar yang keras tak bersuara yang terjadi apabila artikulatornya ialah pangkal lidah dan artikulator pasifnya adalah langitlangit lunak.

Pada kata selincis dan solincis tersebut termasuk monoftong meskipun berbeda posisi lidah ketika mengucapkannya. Jika vokal e pada kata selincis, lidah dalam posisi madya atas, gerak lidah bagian depan, striktur semi tertutup, serta bentuk bibir yang tak bulat. Sedangkan vokal o lidah dalam posisi madya atas, gerak lidah bagian belakang, striktur semi tertutup serta bentuk bibir yang bulat.

Pada kata semmur jering dan sommur joring memiliki pengulangan vokal pada posisi yang sama dalam kedua kata tersebut. Jika vokal $\underline{e}$ tinggi lidah berada pada posisi madya atas, striktur semi tertutup, dan bentuk bibir tak bulat. Sedangkan vokal o lidah dalam posisi madya atas, gerak lidah bagian belakang, striktur semi tertutup serta bentuk bibir yang bulat.

Pada kata ketupat dan katupat tersebut termasuk monoftong meskipun berbeda posisi lidah ketika mengucapkannya. Jika vokal e pada kata selincis, lidah dalam posisi madya atas, gerak lidah bagian depan, striktur semi tertutup, serta bentuk bibir yang tak bulat. Sedangkan vokal a rendah lidah berada dibawah, striktur terbuka dan bentuk bibir tak bulat.

Pada kata keripik dan kuripik tersebut termasuk monoftong meskipun berbeda posisi lidah ketika mengucapkannya. Jika vokal e pada kata selincis, lidah dalam posisi madya atas, gerak lidah bagian depan, striktur semi tertutup, serta bentuk bibir yang tak bulat. Sedangkan vokal $\underline{u}$ lidah dalam posisi madya atas, gerak lidah bagian belakang, striktur semi tertutup serta bentuk bibir yang bulat.

Pada kata uwai inum dan way nginum, perbedaannya sangat terlihat. Pada kata uwai, mengunakan vokal i yang merupakan monoftong dengan posisi lidah tinggi atas, gerak lidah bagian depan, striktur tertutup dan bentuk bibir tidak bulat. Sedangkan pada kata uwai nginum mengunakan 2 konsonan yaitu konsonan y dan $\eta(\mathrm{ng})$. Konsonan y merupakan semi vokal medio palatal yang terjadi bila artikulator aktifnya ialah tengah lidah dan artikulator pasifnya adalah langit-langit keras sedangkan konsonan $\mathrm{n}(\mathrm{ng})$ merupakan konsonan nasal dorso velar yang terjadi apabila proses artikulotoris itu artikulator aktifnya pangkal lidah dan artikulator pasifnya adalah langit-langit lunak sehingga pita suara ikut bergetar maka nasal bersuara.

Pada kata je'ruk dan joruk merupakan monoftong yang termasuk ke dalam vokal semi terbuka atau half open menurut strikturnya. Pada vokal $\underline{e}$ ' lidah dalam posisi madya bawah, gerak lidah belakang strikurnya semi tertutup dan bentuk bibir bulat sedangkan vokal o' lidah dalam posisi madya bawah, gerak lidah bagian belakang, striktur semi terbuka serta bentuk bibir yang bulat.

Pada kata samsam mengunakan vokal a dan konsonan $\underline{s}, \underline{m}$, sedangkan pada kata bekisam mengunakan vokal $\underline{e}, \underline{i}$ dan konsonan $\underline{b}, \underline{k}$. Vokal $\underline{a}, \underline{e}, \underline{i}$ merupakan monoftong. Striktur vokal $\underline{e}$ (semi tertutup), vokal $\underline{a}$ (terbuka) dan vokal $\underline{i}$ (tertutup) sedangkan konsonan $\underline{s}, \underline{m}, \underline{b}$, dan $\underline{k}$ memiliki cara artikulasi berbeda. Jika konsonan $\underline{b}$ merupakan nasal tak bersuara, konsonan $\mathrm{m}$ merupakan nasal bilabial, konsonan $\underline{\mathrm{s}}$ merupakan geseran atau frikatif lamino alveolar dan konsonan $\underline{\mathrm{k}}$ merupakan hambat letup dorso velar.

Pada kata kani'an dan kanian sama-sama monoftong yang serupa tapi tak sama. Jika pada kata kani'an mengunakan vokal i' posisi lidah tinggi atas, gerak lidah bagian depan, striktur tertutup, dan bentuk bibir tak bulat. Sedangkan pada kata kata kanian mengunakan vokal i posisi lidah tinggi bawah, gerak lidah bagian depan, striktur semi tertutup dan bentuk bibir tak bulat.

Pada kata lepot dan lopot memiliki vokal $\underline{e}$ dan o yang merupakan monoftong. Jika vokal e tinggi lidah berada pada posisi madya atas, striktur semi tertutup, dan bentuk bibir tak bulat. Sedangkan vokal o lidah dalam posisi madya atas, gerak lidah bagian belakang, striktur semi tertutup serta bentuk bibir yang bulat. 
ANALISIS FONETIK BAHASA KOMERING DI DESA .... $\mid 5$

Pada kata ekan dan e'kan memiliki monoftong yang mirip tapi tak sama. Jika e pada kata ekan, posisi lidah madya atas, gerak lidah bagian depan, striktur semi tertutup, bentuk bibir tak bulat. Sedangkan vokal e' pada kata e'kan posisi lidah madya, gerak lidah bagian tengah, striktur terbuka, dan bentuk bibir tak bulat.

Fonetik Artikulatoris Narasumber Pertama Tentang Makanan dan Minuman pada Percakapan Sehari-hari. Perbedaan yang paling menonjol adalah dominasi pengunaan monoftong $\underline{e}$ dan monoftong o. Jika pada narasumber $1 \mathrm{~A}$, banyak menggunakan:

Monoftong e berjumlah 10 yang didapat dari kata Serebat, Kemurak, Belu, Selincis, Semmur Jering, Ketupat, Keripik, Lepot, dan Ekan.

Monoftong a berjumlah 2 dari kata Agar dan Samsam.

Monoftong $\underline{u}$ berjumlah 2 dari kata Tempuyak dan Pindang Bawung. Monoftong e' berjumlah 1 yang didapat dari kata E'kan.

Monoftong i berjumlah 1 dari kata Uwai inum dan monoftong i' berjumlah 1 dari kata Kani'an.

Sedangkan pada narasumber $1 \mathrm{~B}$, banyak mengunakan monoftong o yang berjumlah 10 yang didapat dari kata Tempoyak, Agor, Pindang Bawong, Bayom, Hatolui, Bolu, Solincis, Sommur Joring dan Lopot.

Monoftong a berjumlah 2 dari kata Kamurak dan Katupat.

Monoftong $\underline{\underline{u}}$ berjumlah 2 dari kata Surbat dan Kuripik.

Monoftong o' berjumlah 1 dari kata jo'ruk.

Narasumber $1 \mathrm{~A}$ dominasi pengunaan monoftong $\underline{e}$ ini merujuk pada pengunaan artikulatoris yang paling banyak digunakan adalah lidah dengan gerak lidah bagian depan dan dengan posisi bibir yang tidak bulat. Sedangkan pada narasumber 1B dominasi pengunaan monoftong $\underline{0}$ ini merujuk pada pengunaan artikulatoris yang paling banyak digunakan adalah dengan gerak lidah bagian belakang dan dengan posisi bibir yang bulat.

Perbedaan pengunaan konsonan pada narasumber $1 \mathrm{~A}$ dan 1B. Pada narasumber $1 \mathrm{~A}$ ditemukan konsonan $\underline{h}$ atau disebut geseran/frikatif laringal yang berjumlah 2 dari kata hayom dan tahlui.

(1) Konsonan $\underline{t}$ atau disebut hambat letup tidak bersuara berjumlah 1 dari kata tahlui.

(2) Konsonan $\underline{b}$ atau disebut hambat letup bersuara berjumlah 2 dari kata bayom dan bekisam.

(3) Konsonan $\underline{\mathrm{k}}$ atau disebut hambat letup dorso velar berjumlah 2 dari kata kukkuk.

Konsonan s berjumlah 1 atau disebut geseran/frikatif lamino alveolar dari kata samsam.

Konsonan $\underline{m}$ atau nasal bilabial berjumlah 1 dari kata samsam. Sehingga jika dilihat secara artikulatoris yang jumlahnya paling banyak digunakan adalah konsonan hambat letup yang diwakilkan oleh konsonan $\underline{\mathrm{h}}, \underline{\mathrm{b}}$, dan $\underline{\mathrm{k}}$.

Pada narasumber $1 \mathrm{~B}$ ditemukan konsonan $\mathrm{h}$ atau disebut geseran/frikatif laringal yang berjumlah 2 dari kata humbu-humbu dan hatolui.

Konsonan $\underline{t}$ atau disebut hambat letup tidak bersuara berjumlah 1 dari kata hatolui.

Konsonan $\underline{b}$ atau disebut hambat letup bersuara berjumlah 2 dari kata bayom dan bekisam.

Konsonan $\underline{\mathrm{k}}$ atau disebut hambat letup dorso velar berjumlah 1 dari kata kukuk.

Konsonan s berjumlah 1 atau disebut geseran/frikatif lamino alveolar dari kata samsam.

Konsonan ngatau nasal dorso veral berjumlah 1 dari kata uway nginum.

Konsonan y atau semivokal medio palatal berjumlah 1 dari kata uway nginum. Sehingga jika dilihat secara artikulatoris yang jumlahnya paling banyak digunakan adalah konsonan hambat letup yang diwakilkan oleh konsonan $\underline{\mathrm{h}} \underline{\mathrm{b}} \underline{\mathrm{b}}$, dan $\underline{\mathrm{k}}$, meskipun ditemukan juga artikulatoris $\underline{\mathrm{ng}}$ dan konsonan $\underline{\mathrm{y}}$ yang tidak ditemukan pada narasumber $1 \mathrm{~A}$.

Fonetik Artikulatoris Narasumber Kedua Tentang Kata Sifat pada Percakapan Sehari-hari

Pada kata akor dan akur memiliki vokal $\underline{u}$ dan $\underline{o}$ yang merupakan monoftong. Jika vokal o lidah dalam posisi madya atas, gerak lidah bagian belakang, striktur semi tertutup serta bentuk bibir yang bulat. Sedangkan vokal $\underline{u}$ lidah dalam posisi madya atas, gerak lidah bagian belakang, striktur semi tertutup serta bentuk bibir yang bulat.

Pada kata berak dan borak memiliki vokal $\underline{\text { e dan }}$ o yang merupakan monoftong. Jika vokal e tinggi lidah berada pada posisi madya atas, striktur semi tertutup, dan bentuk bibir tak bulat. Sedangkan vokal o lidah dalam posisi madya atas, gerak lidah bagian belakang, striktur semi tertutup serta bentuk bibir yang bulat.

Pada kata amoh dan amuh memiliki vokal $\underline{o}$ dan $\underline{u}$ yang merupakan monoftong. Jika vokal o lidah dalam posisi madya atas, gerak lidah bagian belakang, striktur semi tertutup serta bentuk bibir yang bulat. Sedangkan vokal $\underline{u}$ lidah dalam posisi madya atas, gerak lidah bagian belakang, striktur semi 
tertutup serta bentuk bibir yang bulat.

Pada kata dengi dan dongi memiliki vokal $\underline{e}$ dan o yang merupakan monoftong. Jika vokal e tinggi lidah berada pada posisi madya atas, striktur semi tertutup, dan bentuk bibir tak bulat. Sedangkan vokal o lidah dalam posisi madya atas, gerak lidah bagian belakang, striktur semi tertutup serta bentuk bibir yang bulat.

Pada kata deros dan doros memiliki vokal $\underline{\text { e dan }}$ o yang merupakan monoftong. Jika vokal e tinggi lidah berada pada posisi madya atas, striktur semi tertutup, dan bentuk bibir tak bulat. Sedangkan vokal o lidah dalam posisi madya atas, gerak lidah bagian belakang, striktur semi tertutup serta bentuk bibir yang bulat.

Pada kata layau dan galau memiliki konsonan I, y, dan g. Jika konsonan y merupakan semi vokal medio palatal yang terjadi bila artikulator aktifnya ialah tengah lidah dan artikulator pasifnya adalah langit-langit keras. Sedangkan konsonan $\mathrm{g}$ merupakan hambat letup dorso velar terjadi bila artikulator aktifnya ialah pangkal lidah dan artikulator pasifnya langit-langit lunak bersuara. Serta konsonan ! merupakan sampingan atau laterals apiko alveolar yang strikturnya renggang lebarm tempat artikulasinya ujung lidah dengan gusi.

Pada kata gering dan goring memiliki vokal $\underline{e}$ dan $\underline{o}$ yang merupakan monoftong. Jika vokal $\underline{\mathrm{e}}$ tinggi lidah berada pada posisi madya atas, striktur semi tertutup, dan bentuk bibir tak bulat. Sedangkan vokal o lidah dalam posisi madya atas, gerak lidah bagian belakang, striktur semi tertutup serta bentuk bibir yang bulat.

Pada kata jegol dan jogol memiliki vokal e dan o yang merupakan monoftong. Jika vokal e tinggi lidah berada pada posisi madya atas, striktur semi tertutup, dan bentuk bibir tak bulat. Sedangkan vokal o lidah dalam posisi madya atas, gerak lidah bagian belakang, striktur semi tertutup serta bentuk bibir yang bulat.

Pada kata lesu dan losu memiliki vokal $\underline{e}$ dan $\underline{o}$ yang merupakan monoftong. Jika vokal $\underline{e}$ tinggi lidah berada pada posisi madya atas, striktur semi tertutup, dan bentuk bibir tak bulat. Sedangkan vokal o lidah dalam posisi madya atas, gerak lidah bagian belakang, striktur semi tertutup serta bentuk bibir yang bulat.

Pada kata kacay dan kacai memiliki perbedaan pengunaan vokal dan konsonan yang terdengar mirip dan hampir sama. Jika konsonan y merupakan semi vokal medio palatal yang terjadi bila artikulator aktifnya ialah tengah lidah dan artikulator pasifnya adalah langit-langit keras. Sedangkan pada kata kata kanian mengunakan vokal i posisi lidah tinggi bawah, gerak lidah bagian depan, striktur semi tertutup dan bentuk bibir tak bulat.

Pada kata sara dan saro tersebut yang menunjukkan striktur yaitu vokal a dan o yang merupakan vokal terbuka atau open vowels. Vokal tersebut dibentuk dengan lidah dalam posisi serendah mungkin, kira-kira pada garis yang menghubungkan antara a dan $\underline{0}$.

Pada kata tengi dan tongi memiliki vokal $\underline{e}$ dan $\underline{o}$ yang merupakan monoftong. Jika vokal $\underline{e}$ tinggi lidah berada pada posisi madya atas, struktur semi tertutup, dan bentuk bibir tak bulat. Sedangkan vokal o lidah dalam posisi madya atas, gerak lidah bagian belakang, striktur semi tertutup serta bentuk bibir yang bulat.

Pada kata helau dan holau memiliki vokal $\underline{e}$ dan $\underline{o}$ yang merupakan monoftong. Jika vokal $\underline{e}$ tinggi lidah berada pada posisi madya atas, striktur semi tertutup, dan bentuk bibir tak bulat. Sedangkan vokal o lidah dalam posisi madya atas, gerak lidah bagian belakang, striktur semi tertutup serta bentuk bibir yang bulat.

Pada kata lenat dan lonat memiliki vokal $\underline{e}$ dan $\underline{o}$ yang merupakan monoftong. Jika vokal $\underline{e}$ tinggi lidah berada pada posisi madya atas, striktur semi tertutup, dan bentuk bibir tak bulat. Sedangkan vokal o lidah dalam posisi madya atas, gerak lidah bagian belakang, striktur semi tertutup serta bentuk bibir yang bulat.

Pada kata lemot dan lonat memiliki vokal $\underline{e}$ dan $\underline{o}$ yang merupakan monoftong. Jika vokal $\underline{e}$ tinggi lidah berada pada posisi madya atas, striktur semi tertutup, dan bentuk bibir tak bulat. Sedangkan vokal o lidah dalam posisi madya atas, gerak lidah bagian belakang, striktur semi tertutup serta bentuk bibir yang bulat.

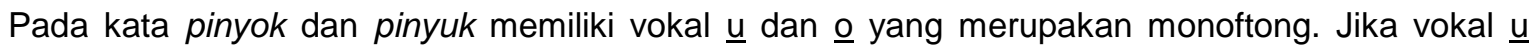
tinggi lidah berada pada posisi madya atas, striktur semi tertutup, dan bentuk bibir tak bulat. Sedangkan vokal o lidah dalam posisi madya atas, gerak lidah bagian belakang, striktur semi tertutup serta bentuk bibir yang bulat.

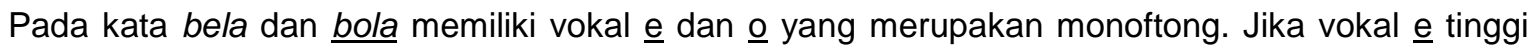


ANALISIS FONETIK BAHASA KOMERING DI DESA .... $\left.\right|_{7}$

lidah berada pada posisi madya atas, striktur semi tertutup, dan bentuk bibir tak bulat. Sedangkan vokal o lidah dalam posisi madya atas, gerak lidah bagian belakang, striktur semi tertutup serta bentuk bibir yang bulat.

Pada kata pedok dan podok memiliki vokal $\underline{e}$ dan o yang merupakan monoftong. Jika vokal $\underline{e}$ tinggi lidah berada pada posisi madya atas, striktur semi tertutup, dan bentuk bibir tak bulat. Sedangkan vokal o lidah dalam posisi madya atas, gerak lidah bagian belakang, striktur semi tertutup serta bentuk bibir yang bulat.

Pada kata betoh dan botoh memiliki vokal $\underline{e}$ dan $\underline{o}$ yang merupakan monoftong. Jika vokal $\underline{e}$ tinggi lidah berada pada posisi madya atas, striktur semi tertutup, dan bentuk bibir tak bulat. Sedangkan vokal o lidah dalam posisi madya atas, gerak lidah bagian belakang, striktur semi tertutup serta bentuk bibir yang bulat.

Pada kata renik dan ronik memiliki vokal $\underline{e}$ dan $\underline{o}$ yang merupakan monoftong. Jika vokal $\underline{e}$ tinggi lidah berada pada posisi madya atas, striktur semi tertutup, dan bentuk bibir tak bulat. Sedangkan vokal o lidah dalam posisi madya atas, gerak lidah bagian belakang, striktur semi tertutup serta bentuk bibir yang bulat.

Fonetik Artikulatoris Narasumber Kedua Tentang Kata Sifat pada Percakapan Sehari-hari. Perbedaan yang paling menonjol adalah dominasi pengunaan monoftong e dan monoftong $\underline{0}$. Jika pada narasumber $1 \mathrm{~A}$, banyak mengunakan monoftong e berjumlah 15 yang didapat dari kata berak, dengi, deros, gering, jegol, lesu, tengi, helau, lenat, lemot, bela, pedok, betoh, dan pedok. Monoftong u berjumlah 3 dari kata akur, amuh, dan pinyuk. Monoftong i berjumlah 1 dari kata Uwai inum. Sedangkan pada narasumber $1 \mathrm{~B}$, hanya mengunakan monoftong o yang berjumlah 18 yang didapat dari kata akor, borak, amoh, dongi, doros, goring, jogol, losu, saro, tongi, holau, lonat, lomot, pinyok, jogol, bola, podok, ronik dan botoh.

Pada narasumber $2 \mathrm{~A}$ dominasi pengunaan monoftong $\underline{\mathrm{e}}$ ini merujuk pada pengunaan artikulatoris yang paling banyak digunakan adalah lidah dengan gerak lidah bagian depan dan dengan posisi bibir yang tidak bulat. Sedangkan pada narasumber 2B hanya pengunaan monoftong $\underline{o}$ yang ditemukan ini merujuk pada pengunaan artikulatoris yang digunakan adalah dengan gerak lidah bagian belakang dan dengan posisi bibir yang bulat.

Perbedaan pengunaan konsonan pada narasumber 2A dan 2B. Pada narasumber 2A hanya ditemukan 2 konsonan yaitu konsonan ! dan konsonan $y$ yang masing-masing berjumlah 1 . Konsonan ! atau disebut sampingan/lateral apiko alveolar yang berjumlah 1 dari kata layau. Konsonan $y$ atau semivokal medio palatal berjumlah 1 dari kata layau. Sehingga dapat dikatakan bahwa pada narasumber $2 \mathrm{~A}$ secara fonetis artikulatoris cenderung pada penggunaan monoftong daripada konsonan.

Pada narasumber 2B hanya ditemukan 3 konsonan yaitu konsonan $\underline{q}_{2} L_{1}$ dan konsonan $y$ yang masing-masing berjumlah 1 . Konsonan $\mathrm{g}$ atau hambat letup dorso veral berjumlah 1 dari kata galau. Konsonan ! atau disebut sampingan/ lateral apiko alveolar yang berjumlah 1 dari kata layau. Konsonan y atau semivokal medio palatal berjumlah 1 dari kata kacay. Sehingga dapat dikatakan bahwa pada narasumber 2B sama seperti narasumber 2A secara fonetis artikulotoris cenderung pada penggunaan monoftong daripada konsonan, meskipun ditemukan juga artikulatoris $y$ yang ditemukan pada narasumber 2A, ini menunjukkan ada kesamaan antara narasumber 1B dan 2B.

Fonetik Artikulatoris Narasumber Ketiga Tentang Kata Kerja pada Percakapan Sehari-hari.

Pada kata mengan dan mongan menunjukkan striktur yaitu vokal e dan o yang merupakan vokal semi terbuka atau half open. Vokal tersebut dibentuk dengan posisi lidah yang diangkat dalam ketinggian sepertiga di atas vokal yang paling rendah atau dua pertiga di bawah vokal tertutup.

Pada kata embani dan ambarani terdengar sama tapi berbeda. Pengunaan vokal $\underline{e}$ dan a serta

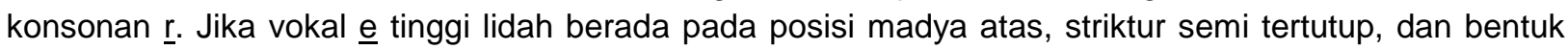
bibir tak bulat. Sedangkan vokal a posisi lidah rendah, lidah berada di bawah, striktur terbuka dan bentuk bibir tak bulat. Serta konsonan $\underline{r}$ merupakan getar apiko alveolar terjadi bila artikulator aktif yang menyebabkan proses mengetar itu ialah ujung lidah dan artikulator pasifnya ialah gusi.

Pada kata bera-buca dan boca-boca memiliki vokal $\underline{\mathrm{e}} \underline{\underline{u}}$ dan $\underline{\mathrm{o}}$ yang merupakan monoftong. Jika vokal $\underline{e}$ tinggi lidah berada pada posisi madya atas, striktur semi tertutup, dan bentuk bibir tak bulat. Sedangkan vokal $\underline{0}$ lidah dalam posisi madya atas, gerak lidah bagian belakang, striktur semi tertutup serta bentuk bibir yang bulat. Serta vokal $\underline{u}$ lidah dalam posisi madya atas, gerak lidah bagian belakang, striktur semi tertutup serta bentuk bibir yang bulat

Pada kata ngambuk dan buambuk memiliki konsonan $\underline{\mathrm{Z}}$ dan $\underline{\mathrm{b}}$ serta vokal $\underline{\mathrm{u}}$. Jika konsonan $\underline{\mathrm{b}}$ merupakan konsonan hambat letup bilabial lunak bersuara yang terjadi bila penghambat artikulor 
aktifnya adalah bibir bawah dan artikulator pasifnya adalah bibir atas. Sedangkan konsonan $n$ (ng) merupakan konsonan nasal dorso velar yang terjadi apabila proses artikulatoris itu artikulator aktifnya pangkal lidah dan artikulotalor pasifnya adalah langit-langit lunak sehingga pita suara ikut bergetar maka nasal bersuara. Sedangkan vokal $\underline{u}$ lidah dalam posisi madya atas, gerak lidah bagian belakang, striktur semi tertutup serta bentuk bibir yang bulat.

Pada kata mandok memiliki konsonan $\underline{m}$ dan andok tidak memiliki konsonan ataupun vokal. Konsonan $\underline{m}$ merupakan konsonan nasal bilabial yang terjadi bila penghambat artikulator aktifnya ialah bibir bawah dan artikulator pasifnya ialah bibir atas.

Pada kata beduwis dan andowis memiliki vokal $\underline{\underline{e}} \underline{\underline{u}}$, dan $\underline{o}$ yang merupakan monoftong selain itu memiliki konsonan $\underline{b}$ dan $\underline{n}$. Jika vokal $\underline{e}$ tinggi lidah berada pada posisi madya atas, striktur semi tertutup, dan bentuk bibir tak bulat. Sedangkan vokal o lidah dalam posisi madya atas, gerak lidah bagian belakang, striktur semi tertutup serta bentuk bibir yang bulat. Serta vokal $\underline{u}$ Sedangkan vokal ulidah dalam posisi madya atas, gerak lidah bagian belakang, striktur semi tertutup serta bentuk bibir yang bulat. Selanjutnya, konsonan $\underline{b}$ merupakan konsonan hambat letup bilabial lunak bersuara yang terjadi bila penghambat artikulor aktifnya adalah bibir bawah dan artikulator pasifnya adalah bibir atas sedangkan konsonan $\underline{\mathrm{d}}$ merupakan konsonan hambat letup apiko palatal yang terjadi bila artikulator aktifnya adalah ujung lidah dan artikulator pasifnya adalah langit-langit keras.

Pada kata paisu, memiliki vokal a merupakan monoftong. Vokal a rendah lidah berada di bawah, striktur terbuka dan bentuk bibir tak bulat. Sedangkan kata pisu tidak memiliki konsonan ataupun vokal

Pada kata pajuh memiliki konsonan $\underline{p}$ dan majuh memiliki konsonan $\underline{m}$. Jika konsonan $\underline{p}$ merupakan konsonan hambat letup bilabial lunak tak bersuara yang terjadi bila penghambat artikulor aktifnya adalah bibir bawah dan artikulator pasifnya adalah bibir atas. Sedangkan konsonan $\mathrm{m}$ merupakan konsonan nasal bilabial yang terjadi bila penghambat artikulator aktifnya ialah bibir bawah dan artikulator pasifnya ialah bibir atas.

Pada kata pijit dan pinyit memiliki konsonan j dan ny. Jika konsonan j merupakan konsonan hambat letup medio palatal terjadi bila artikulator aktifnya adalah tengah lidah dan artikulator pasifnya adalah langit-langit keras. Sedangkan konsonan ñ (ny) adalah konsonan nasal medio palatal yang terjadi bila penghambat artikulatornya aktifnya ialah tengah lidah dan artikulatoris pasifnya adalah langit-langit keras.

Pada kata peretok dan portok memiliki vokal $\underline{e}$ dan $\underline{o}$ yang merupakan monoftong. Jika vokal $\underline{\mathrm{e}}$ tinggi lidah berada pada posisi madya atas, striktur semi tertutup, dan bentuk bibir tak bulat. Sedangkan vokal $\underline{o}$ lidah dalam posisi madya atas, gerak lidah bagian belakang, striktur semi tertutup serta bentuk bibir yang bulat.

Pada kata tedugok memiliki konsonan $\underline{t}$ dan vokal $\underline{e}$ dan pada kata ngadugok memiliki konsonan $\bar{\eta}$ (ng) dan vokal a. Jika vokal $\underline{\text { e }}$ tinggi lidah berada pada posisi madya atas, striktur semi tertutup, dan bentuk bibir tak bulat. Vokal a posisi lidah rendah, lidah berada di bawah, striktur terbuka dan bentuk bibir tak bulat. Sedangkan konsonan $\underline{t}$ adalah konsonan hambat letup apiko dental yang terjadi bila penghambat artikulator aktifnya ialah ujung lidah dan artikulator pasifnya adalah gigi atas, dan konsonan $\underline{\mathrm{n}(\mathrm{ng})}$ merupakan konsonan nasal dorso velar yang terjadi apabila proses artikulatoris itu artikulator aktifnya pangkal lidah dan artikulator pasifnya adalah langit-langit lunak sehingga pita suara ikut bergetar maka nasal bersuara.

Pada kata nasakk dan nasak memiliki konsonan $\underline{\mathrm{k}}$, yang membedakan pengunaan konsonan $\underline{\mathrm{k}}$ yang digandakan dan tunggal. Sehingga konsonan $k$ yang dipakai ganta lebih tajam dibandingkan dengan yang tunggal. Konsonan $\mathrm{k}$ sendiri yaitu konsonan hambat letup dorso velar yang keras tak bersuara yang terjadi apabila artikulatornya ialah pangkal lidah dan artikulator pasifnya adalah langitlangit lunak.

Pada kata numpuh dan nompuh memiliki vokal $\underline{u}$ dan $\underline{o}$ yang merupakan monoftong. Sedangkan vokal o lidah dalam posisi madya atas, gerak lidah bagian belakang, striktur semi tertutup serta bentuk bibir yang bulat. Serta vokal $\underline{u}$ lidah dalam posisi madya atas, gerak lidah bagian belakang, striktur semi tertutup serta bentuk bibir yang bulat.

Pada kata belebas dan bolobas memiliki vokal $\underline{e}$ dan o yang merupakan monoftong. Jika vokal $\underline{\mathrm{e}}$ tinggi lidah berada pada posisi madya atas, striktur semi tertutup, dan bentuk bibir tak bulat. Sedangkan vokal o lidah dalam posisi madya atas, gerak lidah bagian belakang, striktur semi tertutup serta bentuk bibir yang bulat.

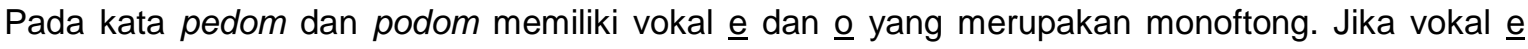
tinggi lidah berada pada posisi madya atas, striktur semi tertutup, dan bentuk bibir tak bulat. Sedangkan 
ANALISIS FONETIK BAHASA KOMERING DI DESA $\ldots . . \quad \mid 9$

vokal o lidah dalam posisi madya atas, gerak lidah bagian belakang, striktur semi tertutup serta bentuk bibir yang bulat.

Pada kata ngeliak dan paliak memiliki konsonan $\mathrm{n}$ dan $\mathrm{p}$. Jika konsonan $\mathrm{n}(\mathrm{ng})$ merupakan konsonan nasal dorso velar yang terjadi apabila proses artikulatoris itu artikulator aktifnya pangkal lidah dan artikulatalor pasifnya adalah langit-langit lunak sehingga pita suara ikut bergetar maka nasal bersuara. Sedangkan konsonan $\underline{p}$ merupakan konsonan hambat letup bilabial lunak tak bersuara yang terjadi bila penghambat artikulor aktifnya adalah bibir bawah dan artikulator pasifnya adalah bibir atas.

Pada kata ngangon dan nompuh memiliki vokal $\underline{a}, \underline{i}, \underline{u}$, dan $\underline{0}$ yang merupakan monoftong. Vokal $\underline{0}$ lidah dalam posisi madya atas, gerak lidah bagian belakang, striktur semi tertutup serta bentuk bibir yang bulat. Vokal $\underline{u}$ lidah dalam posisi madya atas, gerak lidah bagian belakang, striktur semi tertutup serta bentuk bibir yang bulat. Vokal i posisi lidah tinggi bawah, gerak lidah bagian depan, striktur semi tertutup dan bentuk bibir tak bulat. Vokal a rendah lidah berada dibawah, striktur terbuka dan bentuk bibir tak bulat.

Pada kata dacok memiliki konsonan $\underline{\underline{c}}$ dan kata dapok konsonan $\underline{p}$. Jika konsonan $\underline{\mathrm{c}}$ merupakan konsonan hambat letup medio palatal terjadi bila artikulator aktifnya adalah tengah lidah dan artikulator pasifnya adalah langit-langit keras. Sedangkan konsonan ㅁ merupakan konsonan hambat letup bilabial lunak tak bersuara yang terjadi bila penghambat artikulor aktifnya adalah bibir bawah dan artikulator pasifnya adalah bibir atas.

Pada kata sebambangan dan sibambangan tersebut memiliki vokal $\underline{e}$ dan $\underline{i}$. Jika vokal $\underline{e}$ tinggi lidah berada pada posisi madya atas, striktur semi tertutup, dan bentuk bibir tak bulat. Sedangkan vokal posisi lidah tinggi bawah, gerak lidah bagian depan, striktur semi tertutup dan bentuk bibir tak bulat.

Pada kata ngenjuk dan ngojuk memiliki vokal $\underline{e}$ dan o yang merupakan monoftong. Jika vokal $\underline{\mathrm{e}}$ tinggi lidah berada pada posisi madya atas, striktur semi tertutup, dan bentuk bibir tak bulat. Sedangkan vokal o lidah dalam posisi madya atas, gerak lidah bagian belakang, striktur semi tertutup serta bentuk bibir yang bulat.

Perbedaan fonetik artikulatoris narasumber ketiga tentang kata kerja pada percakapan sehari-hari. Perbedaan yang paling menonjol adalah dominasi pengunaan monoftong $\underline{e}$ dan monoftong $\underline{o}$. Jika pada narasumber $1 \mathrm{~A}$, hanya mengunakan monoftong e berjumlah 10 yang didapat dari kata mengan, embani, bera-buca, beduwis, peretok, tedugok, belebas, pedom, sebambangan, dan ngenjuk. Sedangkan pada narasumber 3B, mengunakan monoftong o yang berjumlah 9 yang didapat dari kata mongan, boca-boca, lonat, andowis, portok, nompuh, bolobas, podom, dan ngonjuk. Monoftong a berjumlah 1 dari kata ambarani. Monoftong $\underline{u}$ berjumlah 1 dari kata ngagun. Monoftong i berjumlah 2 dari kata sibambangan dan ngingun.

Narasumber $3 \mathrm{~A}$ yang hanya mengunakan monoftong $\underline{\mathrm{e}}$ ini merujuk pada pengunaan artikulatoris yang paling banyak digunakan adalah lidah dengan gerak lidah bagian depan dan dengan posisi bibir yang tidak bulat. Sedangkan pada narasumber 3B dominasi pengunaan monoftong $\underline{o}$ yang ditemukan ini merujuk pada pengunaan artikulatoris yang digunakan adalah dengan gerak lidah bagian belakang dan dengan posisi bibir yang bulat.

Perbedaan pengunaan konsonan pada narasumber 3A dan 3B banyak ditemukan. Pada narasumber 2A ditemukan 8 jenis konsonan. Konsonan $\Pi$ / (ng) atau disebut nasal dorso veral berjumlah 2 dari kata ngambuk dan ngingun. Konsonan $\mathrm{m}$ atau disebut nasal bilabial yang berjumlah 1 dari kata mandok. Konsonan i atau hambat letup medio palatal berjumlah 1 dari kata pijit. Konsonan $\mathrm{n}$ atau disebut nasal apiko alveolar berjumlah 1 dari kata numpuh. Konsonan $t$ atau disebut hambat letup tak bersuara yang berjumlah 1 dari kata tedugok. Konsonan $\underline{c}$ atau hambat letup medio palatal berjumlah 1 dari kata dacok. Konsonan $\underline{\mathrm{k}}$ atau hambat letup darso veral berjumlah 2 dari kata nasak. Sehingga dapat dikatakan bahwa pada narasumber $2 \mathrm{~A}$ secara fonetis artikulatoris mengunakan konsonan hambat letup $(\mathrm{t}, \mathrm{j}, \mathrm{c}, \mathrm{k})$ dan konsonan nasal ( $\mathrm{n} /(\mathrm{ng}), \mathrm{n}, \mathrm{m})$.

Pada narasumber 3B hanya ditemukan 8 jenis konsonan:

Konsonan $\underline{\mathrm{p}}$ atau hambat letup bilabial berjumlah 2 dari kata paliak. Konsonan $\underline{\mathrm{k}}$ atau disebut.

Konsonan $\underline{k}$ atau hambat letup darso veral berjumlah 1 dari kata nasak.

Konsonan $\underline{r}$ atau getar apiko alveolar berjumlah 1 dari kata ambarani.

Konsonan $\underline{b}$ atau disebut hambat letup bersuara berjumlah 1 dari kata buambuk.

Konsonan $\underline{m}$ atau disebut nasal bilabial yang berjumlah 1 dari kata majuh.

Konsonan $\underline{n}$ atau disebut nasal apiko alveolar berjumlah 1 dari kata andowis.

Konsonan ñ/ny atau disebut nasal media palatal berjumlah 1 dari kata pinyit. 
Dapat dikatakan bahwa secara fonetis artikulotoris mengunakan konsonan hambat letup ( $\underline{p}, \underline{b}, \underline{k})$ dan konsonan nasal ( $\underline{\mathrm{n}} / \mathrm{( \textrm {ng } )}, \underline{\mathrm{n}}, \underline{\mathrm{m}}, \underline{\tilde{n} / \mathrm{ny}})$. Narasumber 2B sama seperti narasumber 2A secara fonetis artikulatoris cenderung pada penggunaan monoftong dari pada konsonan, meskipun ditemukan juga artikulatoris $\underline{r}$ yang ditemukan narasumber $3 \mathrm{~B}$ yang tidak ditemukan pada narasumber $1 \mathrm{~B}$ dan $2 \mathrm{~B}$.

\section{PENUTUP}

Hasil yang diperoleh pada penelitian ini tentang perbedaan fonetik bahasa Komering Desa Kurungan Nyawa dan Desa Riang Bandung Ulu, diteliti secara fonetis artikulatoris yaitu, pada fonetis artikulatoris desa Kurungan Nyawa adalah mengunakan monoftong $\underline{\mathrm{e}}$, artikulator yang digunakan adalah gerak lidah bagian depan dan dengan posisi bibir yang tidak bulat, mengunakan konsonankonsonan hambat letup yang didominasi oleh konsonan $\underline{b}, \underline{k}$, dan $\underline{t}$, mengunakan konsonan $\underline{h}$ atau geseran laringal dan konsonan $\underline{s}$ atau geseran lamino Alveolar yang tidak ditemukan pada fonetis artikulatoris Desa Riang Bandung Ulu.

Sedangkan fonetis artikulatoris Desa Riang Bandung Ulu mengunakan monoftong $\underline{0}$, artikulator yang digunakan adalah gerak lidah bagian belakang dan dengan posisi bibir yang bulat, pengunaan konsonan tidak mendominasi dan mengunakan konsonan konsonan $\underline{r}$ atau getar Apiko Alveolar yang tidak ditemukan pada fonetis artikulatoris Desa Kurungan Nyawa.

Berdasarkan pada penelitian yang telah dilakukan, maka saran-saran yang dapat diberikan peneliti mengharapkan ada penelitian lebih lanjut untuk mendukung penelitian tentang fonetik bahasa Komering dan penelitian-penelitian lainnya yang berkaitan dengan bahasa Komering. Dengan banyaknya penelitian tentang bahasa Komering maka semakin kukuh eksistensi bahasa Komering di tengah-tengah penutur bahasa.

\section{UCAPAN TERIMAKASIH}

Ucapan terimakasih ditujukan kepada ketua STKIP Nurul Huda dan TIM peneliti.

\section{DAFTAR PUSTAKA}

Arikunto, Suharsimi. 2002. Prosedur Penelitian, Suatu Pendekatan Praktek. Jakarta: PT. Rineka Cipta.

Chaer, Abdul. 2013. Fonologi Bahasa Indonesia. Jakarta: Rineka Cipta.

Chaer, Abdul. 2014. Linguistik Umum. Jakarta: Rineka Cipta.

Heiyadi, dedi. 2016. Fonologi Bahasa Indonesia dalam Nuansa Pembelajaran. Tasikmalaya: Universitas Siliwangi Tasikmalaya.

Marsono. 2013. Fonetik. Yogyakarta: Gadjah Mada University Press.

Muin, Abd. 2004. Analisis Kontrastif Bahasa Indonesia dan Bahasa Arab. Jakarta: PT Pustaka Husna Baru.

Moleong, Lexi J. 2017. Metodologi Penelitian Kualitatif. Edisi Revisi. Bandung: Remaja Rosdakarya.

Muslich, Masnur. 2015. Fonologi Bahasa Indonesia: Tinjauan Deskriptif Sistem Bunyi Bahasa Indonesia. Jakarta: Bumi Aksara.

Mukhlisi dkk. 2016. Pengantar Fonologi. Surakarta: Cakrawala Media.

Sutupo. 2006. Metode Penelitian Kualitatif. Surakarta. UNS Press.

Sugiono. 2011. Metode Penelitian Kuantitatif, Kualitatif, dan R\&D. Bandung: Alfabeta.

Suwandi, Sarwiji. 2010. Serba Linguistik. Surakarta: UNS Press dan LPP UNS. Media.

Verhaar, J. M. 2010. Asas-Asas Linguistik Umum. Yogyakarta: UGM Press.

Indah Sulmayanti, Eni Anggraini 
ANALISIS FONETIK BAHASA KOMERING DI DESA .... $\left.\right|_{11}$

Chaer Abdul. 2012. Pengantar Linguistik Edisi Revisi. Yogyakarta: UGM Press.

Wahab, Zanin, dkk. 2012. Sistem Reduplikasi Bahasa Komering. Jakarta: Pusat Pembinaan dan Pengenbangan Bahasa. 